\title{
ANALISIS RASIO PROFITABILITAS UNTUK MENENTUKAN INVESTASI SAHAM PADA PT. UNILEVER, TBK PADA TAHUN PERIODE 2010-2018
}

\author{
Ery Teguh Prasetyo ${ }^{1}$, Triana Yuniati ${ }^{2}$ \\ Prodi Manajemen, Fakultas Ekonomi dan Bisnis, Universitas Bhayangkara Jakarta Raya ${ }^{1}$ \\ Prodi Akuntansi, Fakultas Ekonomi dan Bisnis, Universitas Bhayangkara Jakarta Raya ${ }^{2}$ \\ ery.teguh@ubharajaya.ac.id ${ }^{1}$, triana.yuniati@dsn.ubharajaya.ac.id ${ }^{2}$ \\ Penulis untuk Korespondensi/E-mail: ery.teguh@ubharajaya.ac.id
}

\begin{abstract}
Abstrak
Penelitian ini bertujuan untuk mengetahui pengaruh Rasio Profitabilitas (NPM, PER, ROA dan EPS) terhadap harga saham. Penelitian ini menggunakan pendekatan kuantitatif. Data yang digunakan adalah data sekunder yang diambil dari laporan keuangan perusahaan manufaktur yang terdaftar di Bursa Efek Indonesia dalam hal ini PT. Unilever, Tbk untuk periode 2008 -2018. Analisis data menggunakan analisis regresi berganda. Hasil penelitian menunjukkan bahwa secara parsial variabel Net Profit Margin (NPM) dan R eturn O n A sset (ROA) tidak berpengaruh signifikan terhadap harga saham. Sedangkan variabel Price Earning Ratio (PER), Earnings Per Share (EPS) memiliki pengaruh yang signifikan terhadap harga saham. Hasil Secara Simultan menunjukkan bahwa variabel Net Profit Margin, Price Earning Ratio, Return On Assets, dan Earning Per Share mempunyai pengaruh yang signifikan terhadap harga saham.
\end{abstract}

Kata Kunci : Profit, NPM, PER, ROA, EPS.

\begin{abstract}
This study aims to determine the effect of Profitability Ratios (NPM, PER, ROA and EPS) on stock prices. This study uses a quantitative approach. The data used are secondary data taken from the financial statements of manufacturing companies listed on the Indonesia Stock Exchange, in this case, PT. Unilever, Tbk for the period 2008 -2018. Data were analyzed using multiple regression analysis. The results show that the partial variable Net Profit Margin (NPM) and R eturn $O n$ A sset (ROA) has no significant effect on stock prices. While the variable Price Earning Ratio (PER), Earnings Per Share (EPS)has a significant influence on stock prices. Results In Simultaneous indicates that the variable Net Profit Margin, Price Earning Ratio, Return on Assets, and Earning Per Share has a significant influence on stock prices.
\end{abstract}

Keyword: Profitability, NPM, PER, ROA, EPS. 


\section{PENDAHULUAN}

Text artikel ditulis disini, text artikel ditulis disini, text artikel ditulis disini, text artikel ditulis Perusahaan selalu berusaha untuk meningkatkan kegiatan usahanya menjadi lebih besar, hal ini perlu didukung dengan pemenuhan modal, untuk mencapai tujuan perusahaan, perusahaan dapat menerbitkan saham melalui pasar modal. Pasar modal adalah suatu wadah kegiatan yang dilakukan antara investor dengan perusahaan atau instansi pemerintah dalam jual beli efek berupa saham atau efek lainnya. Saham merupakan bukti kepemilikan perusahaan yang merupakan klaim atas pendapatan perusahaan. Perusahaan yang sahamnya dapat dibeli di Bursa Efek Indonesia disebut Perusahaan Tercatat.

Kenaikan harga saham berpengaruh baik bagi perusahaan karena dapat meningkatkan nilai saham, sebaliknya akan berpengaruh buruk terhadap modal perusahaan karena modal tidak akan bertambah dan akan berhenti karena saham tidak laku dan banyak investor yang mau. menjual saham mereka. (Novasari, 2013). Perkembangan harga saham merupakan proyeksi perkembangan kinerja keuangan perusahaan. Apabila kinerja mengalami peningkatan maka harga saham perusahaan akan mencerminkannya dengan kenaikan harga saham. Untuk menentukan keputusan investasi dapat dilakukan analisis perubahan analisis saham dengan mengevaluasi saham dengan menggunakan analisis teknikal dan analisis fundamental. Peningkatan saham perusahaan akan menarik investor untuk menanamkan modalnya di perusahaan tersebut.

(Wardi, 2011) Analisis fundamental merupakan suatu metode yang dapat digunakan untuk menganalisis saham berdasarkan kondisi fundamental ekonomi suatu perusahaan yang menitikberatkan pada rasio dan kondisi keuangan yang secara langsung maupun tidak langsung mempengaruhi kinerja keuangan suatu perusahaan. Hasil analisis ini sangat penting bagi pihak internal dan eksternal perusahaan. Hasil analisis akan mendeskripsikan kinerja manajemen dan sebagai penilaian atas kemungkinan investasi yang akan ditujukan pada perusahaan melalui analisis laporan keuangan dengan pendekatan rasio keuangan.
Tandelilin dalam (Hadianto, 2008) mengemukakan pendapatnya bahwa dalam melakukan analisis fundamental di tingkat perusahaan, investor harus mendasarkan kerangka kerjanya pada dua komponen utama, yaitu laba per saham (EPS) dan price earning ratio (PER). Ada beberapa alasan yang mendasari bahwa kedua komponen tersebut memiliki pengaruh yang besar dalam menentukan nilai intrinsik suatu saham. Nilai intrinsik dapat diperoleh dengan menghitung kedua komponen tersebut. Alasan lain, dividen yang dibayarkan pada dasarnya dibayarkan dari laba, kemudian ada hubungan antara perubahan laba dengan perubahan harga saham (Hidayat, Akuntansi, Ekonomi, Telkom, \& Telkom, 2013).

(Tita, 2011) Analisis lain yang dilakukan untuk menganalisis saham adalah dengan menggunakan analisis teknikal, analisis ini digunakan untuk memprediksi harga saham dengan cara mengamati perubahan harga tersebut dari waktu ke waktu. Pemikiran yang mendasari analisa teknikal adalah (1) harga saham mencerminkan informasi yang relevan (2) informasi yang ditampilkan perubahan harga masa lalu (3) perubahan harga saham akan mempunyai pola tertentu dan berulang.

Perubahan harga saham dapat dipengaruhi oleh berbagai faktor, melalui analisis dapat diketahui faktor-faktor apa saja yang dominan mempengaruhi perubahan harga saham suatu perusahaan. Rasio profitabilitas merupakan komponen yang sangat penting dalam analisis pergerakan harga saham perusahaan yang terdaftar di BEI, dengan mengetahui profitabilitas sio yang ada pada suatu perusahaan dapat dijadikan pedoman dalam melakukan investasi saham pro. Rasio profitabilitas mengukur seberapa besar kemampuan perusahaan dalam menghasilkan laba. Dalam penelitiannya (Fauziah, Purnawati, \& Leviany, 2017), Gitman (2003) menyatakan bahwa, "Profitabilitas adalah hubungan antara pendapatan dan biaya yang dihasilkan dengan menggunakan aset perusahaan - baik saat ini maupun tetap dalam aktivitas produktif". Rasio ini digunakan untuk mengukur dan membantu mengontrol pendapatan, yaitu dengan meningkatkan penjualan, meningkatkan margin, mendapatkan keuntungan yang lebih besar dari pengeluaran, dan atau kombinasi dari ketiga hal tersebut. 
(Husaini, 2012) Net Profit Margin (NPM) adalah perbandingan antara laba bersih (laba bersih) setelah dikurangi semua biaya termasuk pajak dibandingkan dengan penjualan (Syamsuddin, 2007: 62). Semakin tinggi Net Profit Margin akan menunjukkan efisiensi yang semakin tinggi, sehingga variabel ini menjadi faktor penting yang harus diperhatikan

Rasio profitabilitas berikutnya adalah Return On Assets, In (Sukmawati \& Garsela, 2016) yang dikemukakan oleh Syamsuddin, ROA merupakan indikator bahwa suatu perusahaan dapat menggunakan sumber keuangannya untuk menghasilkan nilai bagi pemegang saham. Semakin besar pencapaian ROA perusahaan, menunjukkan semakin baik kinerja keuangan perusahaan.

(UU Ren Sia \& Tjun Tjun, 2011) PER adalah ukuran untuk menentukan bagaimana pasar memberikan nilai atau harga pada suatu saham perusahaan. Keinginan investor untuk melakukan analisis saham melalui rasio-rasio keuangan seperti PER, disebabkan adanya keinginan investor atau calon investor untuk memperoleh pengembalian investasi saham yang layak. Semakin besar PER suatu saham, maka semakin tinggi bagian laba bersih per saham yang akan ditetapkan.

\section{Rumusan Masalah}

Berdasarkan latar belakang masalah yang telah diuraikan sebelumnya, maka pokok masalah dalam penelitian ini adalah sebagai berikut:

1. Apakah Net Profit Margin (NPM) berpengaruh terhadap Harga Saham?

2. Apakah Price Earning Ratio (PER) mempengaruhi Harga Saham?

3. Apakah Return On Asset (ROA) mempengaruhi Harga?

4. Apakah Earning Per Share (EPS) mempengaruhi Harga Saham?

5. Apakah Net Profit Margin (NPM), Price Earning Ratio (PER), Return On Assets (ROA), Earning Per Share (EPS) secara simultan terhadap harga saham?

\section{Tujuan Penelitian}

1. Menganalisis pengaruh Net Profit Margin (NPM) terhadap harga saham.

2. Menganalisis pengaruh Price Earning Ratio (PER) terhadap harga saham.
3. Untuk menganalisis pengaruh Return On Assets (ROA) terhadap harga saham.

4. Menganalisis pengaruh Earning Per Share (EPS) terhadap harga saham.

5. Menganalisis pengaruh NPM, PER, ROA dan EPS secara simultan terhadap harga saham.

\section{TINJAUAN PUSTAKA}

\section{Teori Persinyalan (Signaling Theory)}

(Hermawanti \& Hidayat, 2014) Dalam penelitian yang dilakukan oleh Winindya Aprilia (2015) dijelaskan bahwa Teori Signallimg menekankan pada pentingnya informasi yang dikeluarkan oleh perusahaan terhadap keputusan investasi pihak di luar perusahaan. Menurut Jogiyanto (2003: 392) informasi yang diumumkan sebagai pengumuman akan memberikan sinyal kepada investor dalam mengambil keputusan investasi. Apabila pengumuman tersebut bernilai positif, maka pasar akan bereaksi ketika pengumuman tersebut diterima pasar, pelaku pasar akan mengartikan dan menganalisa informasi tersebut sebagai sinyal yang baik atau sinyal yang buruk. Sehingga akan menyebabkan perubahan volume perdagangan saham di pasar modal.

Harga saham

(Arkan, 2016) Saham adalah sekuritas

yang paling umum dan secara aktif diperdagangkan di pasar keuangan, mereka dianggap sebagai sumber pendanaan jangka panjang, Saham (saham) memberi pemegang hak untuk menerima keuntungan dalam hal suatu entitas untuk mencapai keuntungan (atau menanggung kerugian sebanyak saham, dan hak untuk memiliki bagian dari perusahaan dan memberikan hak pengelolaan ini baik melalui keanggotaan dalam majelis umum pemegang saham atau oleh Dewan Direksi, oleh karena itu harga saham naik setiap kali laba distribusi terjadi atas dasar kas atau lainnya. (Marcellyna \& Hartini, 2011) harga saham merupakan cerminan dari keputusan investasi, pendanaan (termasuk kebijakan dividen) dan manajemen aset, harga suatu saham per saham yang berlaku di pasar modal. (Ilat \& Pangerapan, 2017) Harga Saham merupakan faktor penting yang harus 
diperhatikan investor dalam berinvestasi, karena harga saham menunjukkan pencapaian perusahaan.Harga saham di pasar modal terdiri dari tiga kategori yaitu high harga est (harga tinggi), harga terendah (harga rendah) dan harga penutupan (harga penutupan).

\section{Margin Laba bersih}

(Utama, 2018) Marjin laba bersih yang tinggi tidak dapat dipastikan akan meningkatkan harga saham perusahaan, namun marjin laba bersih yang tinggi secara logis akan mengundang investor untuk menyediakan dana karena marjin laba bersih menggambarkan keuntungan yang diperoleh perusahaan maka semakin besar pula laba yang diperoleh. oleh sebuah perusahaan. perusahaan maka keuntungan yang akan dibagikan juga besar yang kemudian mempengaruhi investor untuk membeli saham perusahaan, sehingga kejadian ini menggambarkan adanya hukum penawaran dan permintaan. (Dorothy, 2003) Van Horne dan Wachowicz (2005) menyatakan bahwa "Margin Net Income atau Net Profit Margin (NPM) adalah ukuran profitabilitas perusahaan dari hasil penjualan setelah memperhitungkan semua biaya dan pajak penghasilan. Nilai NPM maka semakin produktif kinerja perusahaan, meningkatkan kepercayaan investor dalam menanamkan modalnya, dan hal ini secara tidak langsung mempengaruhi harga saham perusahaan. (Dita \& Murtaqi, 2014) Marjin laba yang tinggi menunjukkan bahwa kinerja keuangan suatu perusahaan semakin meningkat, atau perusahaan dapat mengontrol biaya sehingga memiliki posisi kompetitif yang kuat di industri.Nilai NPM yang tinggi juga menjadi sinyal investor untuk berinvestasi pada suatu perusahaan karena NPM yang lebih tinggi menunjukkan kemampuan perusahaan untuk meningkatkan laba bersih. Laba bersih yang tinggi meningkatkan ekspektasi investor untuk keuntungan yang lebih tinggi.

Price Earning Ratio (PER)

PER menggambarkan hubungan antara harga pasar saham biasa dan laba per saham. PER dipandang oleh investor sebagai ukuran kekuatan suatu perusahaan dalam memperoleh keuntungan jangka panjang. Semakin tinggi PER suatu perusahaan maka semakin baik kemungkinan perusahaan untuk berkembang di masa yang akan datang. (Hermawanti \& Hidayat,
2014) Price Earning Ratio (PER) menggambarkan apresiasi pasar terhadap kemampuan perusahaan dalam menghasilkan laba. Oleh karena itu, rasio ini menggambarkan kesediaan investor untuk membayar sejumlah rupiah untuk setiap rupiah keuntungan perusahaan. PER dihitung dalam satuan waktu.

\section{Return On Asset (ROA)}

(Wulandari, 2015) Return on Assets (ROA) atau sering juga disebut Return on Investment (ROI) adalah rasio profitabilitas yang digunakan untuk mengukur keefektifan suatu perusahaan dalam menghasilkan laba dengan memanfaatkan asetnya. Menurut Ang (1997) ROA adalah rasio antara laba bersih setelah pajak (Net Income After Tax-NIAT) terhadap total aset. Arthur J. Keown, dkk. (2008) menyatakan bahwa "ROA pada aset dapat digunakan sebagai indikator profitabilitas perusahaan. Asset return menentukan besarnya pendapatan yang dihasilkan dari aset perusahaan dengan menghubungkan laba bersih dengan total aset. ROA dapat menggambarkan seberapa efektif suatu perusahaan menggunakan asetnya dalam pendapatan Investopedia menyarankan bahwa: "Angka ROA memberi investor gambaran tentang seberapa efektif perusahaan mengubah uang yang harus diinvestasikan menjadi laba bersih. Semakin tinggi angka ROA semakin baik, karena perusahaan menghasilkan lebih banyak uang dengan investasi yang lebih sedikit "(Idawati \& Wahyudi, 2015).

\section{Laba Per Saham (EPS)}

(Widiyanti et al., 2019) Menurut Fabozzi (2011) Earning per share merupakan perbandingan antara laba yang tersedia bagi pemegang saham biasa (laba setelah pajak dikurangi dividen saham preferen) dengan ratarata tertimbang jumlah saham yang beredar.

\section{Hipotesis}

1. H1: Net Profit Margin (NPM) berpengaruh positif terhadap harga saham.

2. H2: Price Earning Ratio (PER) berpengaruh positif terhadap harga saham.

3. H3: Return on Assets (ROA) berpengaruh positif terhadap harga saham.

4. H4: Earning Per Share (EPS) berpengaruh positif terhadap harga saham. 
5. H5: Nilai NPM, PER, ROA dan EPS berpengaruh positif terhadap harga saham.

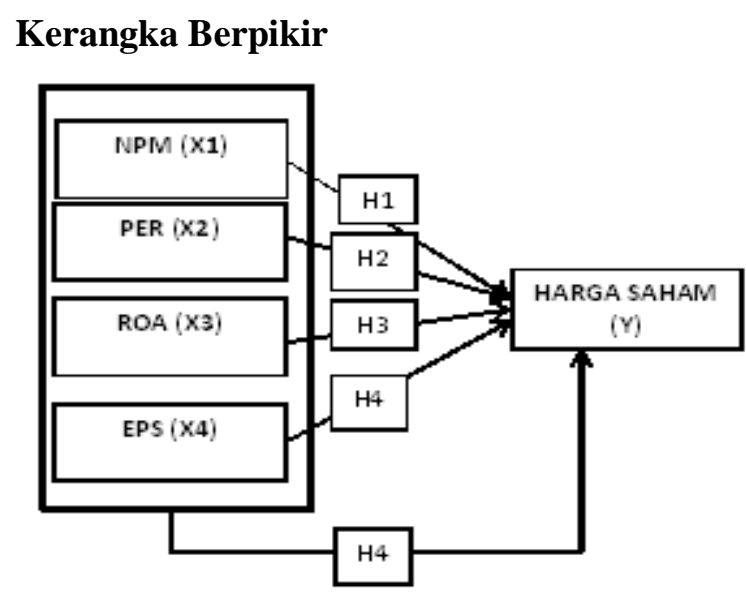

Gambar 1. Kerangka Pemikiran

\section{METODE PENELITIAN}

\section{Jenis Penelitian}

Penelitian ini dapat digolongkan menjadi penelitian kuantitatif yaitu penelitian yang menggunakan angka-angka, mulai dari pengumpulan data, interpretasi data tersebut dan kemunculan hasil. Data yang digunakan adalah data sekunder yaitu laporan keuangan PT. Unilever, Tbk untuk periode 2008 -2018.

Teknik analisis data dengan model regresi berganda, menggunakan metode pengujian hipotesis yang menyatakan hubungan suatu variabel dapat menyebabkan perubahan variabel lain.

\section{PEMBAHASAN HASIL}

1. Rasio Net Profit Margin (X1) yang digunakan untuk menunjukkan kemampuan perusahaan dalam menghasilkan laba bersih setelah dikurangi pajak.

$$
N P M=\frac{\text { Net Profit }}{\text { Sales }}
$$

2. Price Earning Ratio (X2) Merupakan ukuran besar kecilnya keuntungan suatu perusahaan dibandingkan dengan harga pasar saham biasa di masa yang akan datang.

$$
P E R=\frac{\text { Stock Price }}{E P S}
$$

3. Return On Assets (X3) merupakan rasio profitabilitas yang digunakan untuk mengukur keefektifan suatu perusahaan dalam menghasilkan laba dengan memanfaatkan asetnya.

$$
\text { Return On Assets }=\frac{\text { Earning After Tax }}{\text { Total Asset }}
$$

4. Earning Per Share (X4) EPS atau laba per saham merupakan tingkat laba bersih untuk setiap saham yang dapat dicapai perusahaan saat menjalankan operasinya. Laba per saham atau EPS diperoleh dari keuntungan yang tersedia bagi pemegang saham biasa dibagi dengan jumlah rata-rata saham yang beredar.

5. Harga Saham (Y) adalah harga saham di bursa efek pada waktu tertentu yang ditentukan oleh pelaku pasar dan permintaan dan penawaran saham yang bersangkutan di pasar modal. Harga saham yang digunakan dalam penelitian ini adalah harga saham penutupan

\begin{tabular}{|c|c|c|c|c|c|c|}
\hline \multicolumn{7}{|c|}{ Coefficients $^{\text {a }}$} \\
\hline \multirow{2}{*}{\multicolumn{2}{|c|}{ Model }} & \multicolumn{2}{|c|}{ Unstandardized Coefficients } & \multirow{2}{*}{$\begin{array}{c}\text { Standardized } \\
\text { Coefficients }\end{array}$} & \multirow[b]{2}{*}{$\mathrm{t}$} & \multirow[b]{2}{*}{ Sig. } \\
\hline & & B & Std. Error & & & \\
\hline 1 & (Constant) & $-3,340$ & 11,784 & & -283 & .786 \\
\hline & NPM & $-3,055$ & 2,613 & -.574 & -1.169 & .287 \\
\hline & PER & .251 & .067 & .487 & 3,762 & .009 \\
\hline & ROA & .882 & 1,087 & .380 & .811 & .448 \\
\hline & EPS & .059 & .008 & 1,166 & 7,698 & .000 \\
\hline
\end{tabular}

tahunan.

\section{Analisis Regresi}

a. Dependent Variable: PRICE 
Berdasarkan koefisien data diatas dapat diperoleh rumus regresi sebagai berikut:

$$
\begin{gathered}
\mathrm{Y}=-3,340-3,055 \mathrm{X} 1+0,251 \mathrm{X} 2+0,882 \times 3 \\
+0,059+\mathrm{e}
\end{gathered}
$$

Dari model regresi linier berganda di atas, dapat disimpulkan sebagai berikut:

1. Dari persamaan regresi linier berganda di atas diperoleh nilai konstanta $-3,340$. Artinya jika variabel Harga Saham (Y) tidak dipengaruhi oleh tiga variabel independen yaitu (NPM, PER, ROA, dan EPS) bernilai nol maka nilai rata-rata Harga Saham adalah $-3,340$.

2. Variabel NPM bertanda negatif yang artinya NPM memiliki hubungan terbalik dengan harga saham. Atau setiap kenaikan 1\% NPM akan menyebabkan penurunan harga saham sebesar - 3.055, jika semua variabel sudah tetap.

3. Variabel PER bertanda positif artinya PER memiliki hubungan langsung dengan harga saham. Atau setiap kenaikan PER 1\% akan menyebabkan kenaikan harga saham 0,251, jika semua variabel diperbaiki.

4. Variabel ROA bertanda positif artinya ROA berhubungan langsung dengan harga saham. Atau setiap kenaikan ROA sebesar 1\% akan menyebabkan kenaikan harga saham sebesar 0.882, jika semua variabel sudah diperbaiki.

5. Variabel EPS bertanda positif artinya EPS berhubungan langsung dengan harga saham, atau setiap kenaikan EPS sebesar 1\% akan menyebabkan kenaikan harga saham sebesar 0,059, jika semua variabel tetap.

\section{Analisis Hipotesis \\ Partial Test (t test)}

\begin{tabular}{|c|c|c|c|c|c|c|}
\hline \multirow{2}{*}{\multicolumn{2}{|c|}{ Model }} & \multicolumn{2}{|c|}{ Unstandardized Coefficients } & \multirow{2}{*}{$\begin{array}{c}\text { Standardized } \\
\text { Coefficients } \\
\text { Beta }\end{array}$} & \multirow[b]{2}{*}{$\mathrm{t}$} & \multirow[b]{2}{*}{ Sig. } \\
\hline & & $\mathrm{B}$ & Std. Error & & & \\
\hline 1 & (Constant) & $-3,340$ & 11,784 & & -283 & .786 \\
\hline & NPM & $-3,055$ & 2,613 & -.574 & -1.169 & .287 \\
\hline & PER & .251 & .067 & .487 & 3,762 & .009 \\
\hline & ROA & .882 & 1,087 & .380 & .811 & .448 \\
\hline & EPS & .059 & .008 & 1,166 & 7,698 & .000 \\
\hline
\end{tabular}

Coefficients $^{\text {a }}$

a. Dependent Variable: PRICE

1. Pengaruh Net Profit Margin (X 1) terhadap harga saham (Y), berdasarkan tabel di atas diperoleh hasil analisis t-value 1,169 <t tabel 2,776 dan nilai probabilitas 0,287> 0,05, sehingga Ho diterima dan H1 ditolak maka dapat disimpulkan bahwa Net Profit Margin (NPM) tidak berpengaruh terhadap harga saham. Hasil penelitian ini sejalan dengan penelitian (Pratama \& Erawati, 2016) bahwa Net Profit Margin tidak berpengaruh terhadap harga saham.

2. Pengaruh Price Earning Ratio (X 2) terhadap Harga Saham (Y), berdasarkan tabel di atas diperoleh hasil analisis nilai uji-t sebesar 3,782> t tabel 2,776 dan nilai Probabilitas
$0,009<0,05$. Sehingga Ho ditolak dan H2 diterima maka dapat disimpulkan bahwa PER berpengaruh signifikan terhadap Harga Saham (Y). Hasil penelitian ini sejalan dengan penelitian yang dilakukan secara empiris oleh (Law Ren Sia \& Tjun Tjun, 2011) bahwa Partial Price Earnings Ratio (PER) berpengaruh signifikan terhadap harga saham, dengan kenaikan PER maka akan berdampak perubahan. Pada harga saham, semakin tinggi PER akan menyebabkan kenaikan harga saham perusahaan.

3. Pengaruh Return On Assets (X 3) Terhadap Harga Saham (Y) Berdasarkan tabel di atas diperoleh hasil analisis dengan t-value 0,811 
$<$ tabel 2,776 dan nilai probabilitas $0,448>$ 0,05 . Jadi dapat disimpulkan bahwa H0 diterima dan $\mathrm{H} 3$ ditolak yang artinya Return On Assets (X3) tidak berpengaruh signifikan terhadap harga saham (Y). Hasil ini sejalan dengan penelitian yang dilakukan oleh (Idawati \& Wahyudi, 2015) yang menunjukkan bahwa ROA tidak berpengaruh terhadap harga saham pada perusahaan pertambangan yang listing di BEI.

4. Pengaruh Earning Per Share (X4) Terhadap Harga Saham (Y) Berdasarkan tabel diatas diperoleh hasil analisis thitung 5,229> t tabel 2,776, dan nilai probabilitas $0,00<0,05$. Sehingga Ho ditolak dan H4 diterima, atau dapat disimpulkan Earning Per Share (X4) berpengaruh signifikan terhadap Harga Saham (Y). Hasil ini sejalan dengan penelitian yang dilakukan (Watung \& Ilat, 2016) bahwa EPS memiliki pengaruh yang signifikan terhadap harga saham pada perusahaan perbankan di Bursa Efek Indonesia periode 2011-2015.

\section{Simultaneous Test (F-Test)}

ANOVA $^{\text {b }}$

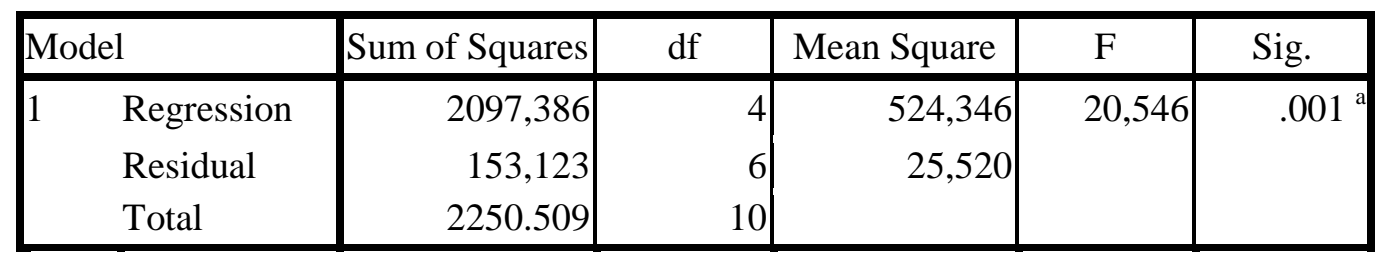

a. Predictors: (Constant), EPS, ROA, PER, NPM

b. Dependent Variable: PRICE

Berdasarkan tabel penelitian diatas menunjukkan nilai $\mathrm{F}$ hitung sebesar 20,546> F tabel sebesar 6,388 dengan nilai probabilitas $0,001<0,05$ sehingga dapat disimpulkan bahwa secara simultan variabel NPM, PER, ROA dan EPS berpengaruh signifikan terhadap Saham. Harga (Y).

\section{Determination Coefficient Test}

Summary Model ${ }^{\text {b }}$

\begin{tabular}{|l|r|r|r|r|r|}
\hline Model & \multicolumn{1}{|c|}{$\mathrm{R}$} & R Square & \multicolumn{1}{c|}{$\begin{array}{c}\text { Adjusted R } \\
\text { Square }\end{array}$} & $\begin{array}{l}\text { Std. Error of } \\
\text { the Estimate }\end{array}$ & Durbin-Watson \\
\hline 1 & $.965^{\mathrm{a}}$ & .932 & .887 & 5.05178 & 2,956 \\
\hline
\end{tabular}

a. Predictors: (Constant), EPS, ROA, PER, NPM

b. Dependent Variable: PRICE

Dari tabel diatas diketahui bahwa nilai detergency (R Square) adalah 0,932 atau dapat disimpulkan Net Profit Margin (NPM), Price Earning Share (PER), Return On Assets (ROA) dan Earning Per Saham (EPS) berpengaruh secara simultan terhadap harga saham sebesar 93,2\%, sedangkan sisanya dipengaruhi oleh variabel lain di luar model regresi itu.

\section{KESIMPULAN}

1. Margin Laba Bersih memiliki hubungan negatif dan tidak berpengaruh signifikan terhadap harga saham pada PT. Unilever, Tbk

2. Price Earning Ratio memiliki hubungan positif dan berpengaruh signifikan terhadap harga saham pada PT. Unilever, Tbk 
3. Return On Assets memiliki hubungan yang positif tetapi tidak berpengaruh signifikan terhadap Harga Saham.

4. Earning Per Share (EPS), memiliki hubungan yang positif dan mempengaruhi harga saham PT. Unilever, Tbk.

5. Net Profit Margin (NPM), Price Earning Share (PER), Return on Assets (ROA) dan Earning Per Share (EPS) secara simultan berpengaruh signifikan terhadap harga saham PT. Unilever, Tbk.

\section{Rekomendasi}

Saran yang dapat diberikan oleh peneliti adalah sebagai berikut.

1. Investor harus mempertimbangkan nilai Price Earning Ratio dan Earning Per Share suatu perusahaan sebagai pertimbangan dalam pengembangan, karena menurut hasil penelitian ini rasio PER dan EPS terbukti mempengaruhi harga saham.

2. Bagi peneliti diharapkan dapat melakukan penelitian dengan menggunakan variabel lain dan perusahaan di sektor lain agar lebih variatif sehingga dapat mendeskripsikan variabel apa saja yang dapat mempengaruhi Harga Saham dan dapat memperluas ruang lingkup penelitian tentang pengaruh rasio keuangan terhadap harga saham

\section{DAFTAR PUSTAKA}

Ardyanto, D. F. (2017). Pengaruh Earning Per Share (EPS). Return on Assets (ROA), Return On Equity (ROE) dan Debt To Equity Ratio (DER) terhadap Harga Saham Perusahaan $L Q 45$ yang Terdaftar di BEI.

Arkan, T. (2016). The Importance of Financial Ratios in Predicting Stock Price Trends : A Case Study in Emerging Markets. 2016(1), 13-26.

https://doi.org/10.18276/frfu.2016.79-01

Dita, A. H., \& Murtaqi, I. (2014). Pengaruh Net Profit Margin, Price To Book Value dan Debt To Equity Ratio terhadap Return Saham Pada Industri Barang Konsumsi Indonesia. Jurnal Bisnis Dan Manajemen, 3 (3), 305-315. Diambil dari http://journal.sbm.itb.ac.id/index.php/jbm/ article/view/1214

Dorothy, G. (2003). The Influence of Earning Per Share (EPS), Price Earning Ratio (PER), Net Profit Margin (NPM), and Return On Assets (ROA) Against the Share Price of PT. Unilever, Tbk. and Subsidiaries. 1(2004), 69-71.

Fauziah, U., Purnawati, H., \& Leviany, T. (2017). Pengaruh Current Ratio dan Debt To Capital Ratio Terhadap Return On Assets. Jurnal SIKAP (Sistem Informasi, Keuangan, Auditing Dan Perpajakan), 2 (1), 63. https://doi.org/10.32897/sikap.v2i1.63

Hermawanti, P., \& Hidayat, W. (2014). Pengaruh Earning Per Share (EPS), Price Earning Ratio (PER), Debt To Equity Ratio (DER), Return On Assets (ROA) dan Return On Equity (ROE) Terhadap Harga Saham Studi Kasus pada Perusahaan Go Public Property dan Real Estate Sektor Terdaftar di BEI.

Hidayat, M. R. (2013). Pengaruh Earning Per Share (EPS), Price Earning Ratio (PER), dan Dividend Payout Ratio (DPR) terhadap Return Saham Perusahaan (Studi di Sektor Properti dan Real Estate di Bursa Efek Indonesia Periode 2011-2013)

Husaini, A. (2012). Pengaruh Variabel Return On Assets, Return On Equity, Net Profit Margin dan Earnings Per Share Terhadap Harga Saham Perusahaan. Jurnal Administrasi Bisnis, 6 (1), 45-49.

Idawati, W., \& Wahyudi, A. (2015). Pengaruh Earning Per Share (EPS) dan Return On Assets (ROA) Terhadap Harga Saham pada Perusahaan Pertambangan Batubara Yang Terdaftar di Bursa Efek Indonesia. Jurnal Pengembangan Sumber Daya dan Manajemen, 7, 79-92.

Ilat, G. E. Y. E. V., \& Pangerapan, S. (2017). The Influence of Return on Assets (Roa), Return on Equity (RoE), Net Profit Margin $(\mathrm{Npm})$, and Earning Per Share (EPS) on the Stock Prices of Companies That Are Included in the Lq45 Index on the Indonesia Stock Exchange in the Period of 2013-2015. Jurnal EMBA: Jurnal Riset Ekonomi, Manajemen, Bisnis Dan Akuntansi, 5(1), 105-114.

Islam, M. R., Khan, T. R., Choudhury, T. T., 
Adnan, A. M., \& Senior Lecturer, 1. (2014). How Earning Per Share (EPS) Affects on Share Price and Firm Value. European Journal of Business and ManagementOnline), 6(17), 2222-2839.

Kumar, P. (2017). Impact of earning per share and price earning ratio on market of share: A study on auto sector in India. International Journal of Research Granthaalayah, 5(2), 113-118. https://doi.org/10.5281/zenodo.345456

Law Ren Sia, V., \& Tjun Tjun, L. (2011). Price Earnings Ratio Against Vice Law Price Ren Sia Lauw Tjun Tjun Preliminary. Akuntansi, 3(2), 136-158.

Marcellyna, F., \& Hartini, T. (2011). Pengaruh Earning Per Share (EPS) terhadap Harga Saham Lq45 di Bursa Efek Indonesia (BEI). Jurnal Akuntansi STIE MDP, 1-7.

Novasari, E. (2013). Pengaruh Per, Eps, Roa dan Der terhadap Harga Saham Perusahaan Sub Sektor Industri Tekstil yang Go Public di Bursa Efek. Dalam Pengembangan (Vol. 134).

Patriawan, D. (2011). Analisis pengaruh laba per saham (EPS), return on equity (ROE), dan debt to equity ratio (DER) terhadap harga saham pada perusahaan perdagangan grosir dan eceran yang terdaftar di Bursa. Jurnal Ekonomi Akuntansi, 5 (2), 1-72.

Robbetze, N., Africa, S., Villiers, R. De, Africa, S., Harmse, L., \& Africa, S. (2017). The Effect Of Earnings Per Share Categories On Share Price Behaviour: Some South
African Evidence. 33(1), 141-152.

Sukmawati, F., \& Garsela, I. (2016). The Effect of Return on Assets and Return on Equity to the Stock Price. 15, 53-57. https://doi.org/10.2991/gcbme-16.2016.8

Tita, D. (2011). Effect of Financial Ratios, Dividend Sales Growth on Share Prices. Jurnal Bisnis Dan Akuntansi, 13(1), 5766.

Utama, E. W. (2018). Pengaruh Net Profit Margin Terhadap Harga Saham PT. Unilever, Tbk. 2011-2016. Jurnal Mitra Manajemen (JMM Online) Pengaruh Net Profit Margin Terhadap Harga Saham PT. Unile, 2 (1), 35-43.

Wardi, J. (2011). Pengaruh Current Ratio, Debt to Equity Ratio, Return on Equity dan Earning Per Share terhadap Harga Saham. 127-147.

Widiyanti, M., Adam, M., \& Isnurhadi, I. (2019). Pengaruh Kinerja Perusahaan terhadap Earing per Saham dengan Dividend Payout Ratio sebagai Variabel Intervening pada Perusahaan LQ 45. Acta Universitatis Danubius. Economica, 15 (4), 286-292.

Wulandari, C. (2015). Analisis Pengaruh Return on Assets (ROA), Earning Per Share (EPS), Debt to Equity Ratio (DER) Terhadap Price to Book Value (PBV) pada Perusahaan Manufaktur. Universitas Muhammadiyah Surakarta. 